\title{
A DAILY LIFE LYRIC SONG AS A FOLKLORE TEXT
}

\author{
Prof. Lübov KOPANYTSIA
}

\begin{abstract}
The article elucidates the place of a daily life lyric song among other folk genres with their genesis and constituent elements rooted in a myth and a ritual. The role of the primordial thinking and the traditional techniques of reproduction of the world outlook experience are considered. In particular, the author emphasizes that a lyric song is not so much a description of the surrounding world or a reflection of the performer's feelings as reproduction of the adjusted scheme of the people's Weltanschauung which function is closely connected with magic actions, divinations and charms. This predetermines the well-established form of images and plots typical for lyric songs as its task is not to describe the world or new events but to preserve the archaic scheme of the world perception to be applied to the everyday life situations for their comprehension within the timeless outlook. Surely, it doesn't preclude such role of an everyday life song as discharge of excessive, mostly negative feelings. This preconditions the main features of an everyday life lyric song: stereotype and repetition, the sensual and emotional way of experiencing the reality, social communicability and the metaphoric form of comprehension of the world.
\end{abstract}

Keywords: Lyric Song, Myth, Ritual, Creative Principle, Semifunctional Symbolic Mechanism

\section{Introduction}

A source of the lyric genre of the verbal poetical creation is regarded as a ritual discourse, i.e. ritual poetry with its symbolic style as a chronologically and genetically initial form. Indeed, the verbal lyrics have much in common with the calendar and nuptial songs the origin of which is more ancient than that of the lyric ones. Most researchers of verbal literature (O.Bodianskyi, O.Potebnia, O.Veselovskyi, F.Kolessa, V.Propp, O.Dei, N.Kolpakova et al.) tend to the idea that lyric songs were conceived in the depths of a ritual having separated from conjuring and felicitating ones and lamentations. However, as an ethnos develops, its Weltanschauung changes, the kinds of the folk culture evolve, and the song creation dominants are transformed as well. Just on the verge of $16^{\text {th }}$ and $17^{\text {th }}$ centuries, the lyric songs existed absolutely independently, with their range of themes, ideas, images and their regularities of artistic life typification. The daily lyric songs demonstrate not only the appearance of new themes associated with various areas of human life (individual, family, social) but also the functional changes: their magic function is substituted for the aesthetic one.

We could mention a whole series of common or close motives and images of lyric songs and other verbal literature genres, which would once again support the folklorists' idea on the genetic links of the song genre with such kinds and genres as ritual songs, charm, ballads, tales etc. However, in that case, it should be first said about a metalanguage and even a common logic of the archaic thinking which were earlier perfectly interpreted by A.Freidenberg in his lectures from 'The

\footnotetext{
The article elucidates the promising lines of genre interpretation of the genesis and evolution of the verbal lyrics and the mythical-andritual analysis principles of a song text.

Taras Shevchenko National University of Kyiv
} 
Introduction into the Antique Folklore'. According to his conclusions, the primordial thinking is anti-causal, and there is no sense to seek a consequence from a cause because 'a cause of a phenomenon lied for it (i.e. primordial thinking - L.K.) in an adjacent phenomenon. Freidenberg emphasizes that it was a way in which causes and consequences interlaced forming a circle, a closed line' (Freidenberg, 1998, p. 18-19). This quotation gives a rather convincing explanation of not so much the archaic thinking logic but describes the 'individual' creation of the folklore tradition and creative subject's consciousness. The Freidenberg's philosophical definition, anticausality of the primordial thinking, in the analysis of folklore song poetics may have a projection on 'assimilation' of the 'specifics' and mythological thinking technique in it as well as a description of the verbal culture dynamics. Indeed, if the aim of a charming text is a verbal magic influence on a situation for the purpose of changing it, the context representation in a lyric song contributes to formation of a 'mythological variant', arousal of the main signs, functions, characteristics of 'constructive forms of consciousness' (described by E. Cassirer) in the human imagination and memory for communicating an emotional state of an individual and influence on it. Though one may quite admit the version of suitability of the mythological thinking for the requirements of verbal poetry, however, a folklorist is always interested in the process of creation of a poetic text.

However, in the modern folklore studies, the issue of the origin and historic development of out-ofritual lyrics has not been studied to the appropriate extent yet. Likewise, the time of origin of those songs that are known to us due to the records of $18^{\text {th }}-19^{\text {th }}$ centuries and how they evolved in the early period of their existence until the scientific recording, has not been ascertained for certain. However, while some researchers tend to believe that a lyric song usually has no dating musicologists suppose that formation of a genre and its musical language dates from $16^{\text {th }}$ and $17^{\text {th }}$ centuries. Finally, till the end of $18^{\text {th }}$ century, a daily life lyric song had not been only developing in all of the most important cycles and genre varieties but also reached its fullest flower, the evidence of which is the first records of its examples.

However, in order to find answers to these questions, what is important to understand first of all is that lyric songs are representatives of their time, so undoubtedly they are the most important monuments of the folk Weltanschauung, traditions and history of culture. But everything that has been said about the folk song is not yet a reason to believe that it just illustrates human life. From whatever point of view we would look at the issue of origin and historic development of folklore lyrics, it's easy to notice that its elementary poetic motives and images model the human behaviour, thinking, ideals without clearly defined time and space, in the distinctive and complete integrity. In this context, songs play a role of a cultural form of conscious symbolic transmission of historic, psychological and aesthetic experience of the ethnos like magic, ritual and myth. And then, it could be said that a national song text is a second 'myth' and, to a certain extent, a combination of various ideologemes including those which reflect the concept about the world and life, provide behavioural guidelines, designate views on the human, interpersonal relations and individual activity, feelings and intimate life. And that's why in this role, the objects of study of the history of people, national distinctive character and mentality are not only such monuments of the spiritual culture as historic songs and ballads but verbal lyrics as well.

\section{The Connection Between Lyric Songs and Folklore}

Everything testifies that the process of formation of the lyric song genre was long enough. Some its motives, images, composition building techniques and formation of the poetic style are very ancient although the final formation of the genre phenomenon dates from relatively later times. However, the studies of the verbal lyrics reveal that in formation of its poetics the primordial 
poetry traditions are not of such importance as existence of common symbolic paradigms which are inseparable from myth-creation or mythic-poetic concepts of the world, the mythical Weltanschauung and ritual, which explain their semantics. Certainly, folk lyric songs as a genre phenomenon cannot be examined (even as a long and complex process) but as a result of their direct distinguishing from the syncretic mythological consciousness. While we cannot adopt the mythological and ritualistic theory for analysis of the genesis of lyric songs completely, we nevertheless may agree that the song creation widely involves intellectual and verbal codes of a myth and a ritual as a model for plots, plotlines and images. A myth as a certain 'pre-language' (according to the philologist V. Toporov) correlates with a folklore piece, a song, from the rule, at the level of the world outlook constants and infinite number of mythological reminiscences and associations which probably came to the folk poetry through a ceremony, through broadened contents of ceremonial texts. But in this case, when a myth and a folklore song correlate through a ceremonial substrate, its motives and mythologisms, even not formed strongly as a complex of mythological conceptions of the world, community, however, bear traces of mythological thinking and a myth.

However, the role of a myth and a ritual in the development of the folk lyrics should not be understood as some 'eternal' models of art but rather vice versa, as pre-roots of a human thought, creation, poetic figurativeness which give birth to a new sense in favour of another one. Or, and this is the first condition of reconstruction of a genre phenomenon, the simplest explanation of such phenomenon should be sought in the fact that there are not separate rituals which are perceived as complexes of genres, themes, plots, motives etc. but those systems of rules, prohibitions, orders, ritual and mythological world outlook categories which are transformed into genres, plots, motives and structural systems. And the second one is the 'cult of emotional experience', the most important purpose of lyric songs: to reveal the sensation of the world by people through expression of its 'emotional impressions' (Potebnia, 1989, p. 505), thoughts and moods which directly coincide with the nature of the mythological view on the world, i.e. emotionally specific.

However, another thing is of importance as well: a lyric song in many aspects of perception and expression of the surrounding and internal world of a man, including the psychological one, involves techniques, symbols, expressive formulae etc. already inveterate in the primordial mythological thinking (for example, parallelism, symbols, metaphor). Undoubtedly, they require special approach for decoding because from the point of view of a modern man, often it is just impossible to explain them. They are those polysemantic, sensual images, 'associative figurative structures' (Denisyuk, 2005, p. 32) that generate all the texts of folklore poetry due to which a picture of the human internal world was reproduced, convincing and well-grounded, from the point of view of the folk consciousness, understanding and explanation of the psychological essence of a man, concealed soul tenderness and its external manifestations were given, where finally a man self-identified and self-specified. They may explain whence the song folklore takes it uniqueness but the contents will be unattainable without taking into consideration their mythological basis, underlying interconnections, ritual and magic, psychological and social functions. Naturally, it is conditioned by primordial syncretism of pieces of the verbal culture known in the O.Veselovskyi's conception, substantiatedin the work 'Three Chapters from Historical Poetics (1899) (Veselovskiy, 1940) which should be understood not so much the combination of heterogeneous elements (dance, singing, music, word, gestures) within one expression as first of all a problem of the Weltanschauung as an expression of the universal nature of the human creation.

The folk song practice is revealing of an infinite cultural code which the author-performer possesses. And in order to understand the secrets of existence of a song, it is necessary to return to the primitive mythology and ritual looking for psychological biography of a man there. A myth and 
a ritual, on the one hand, are a world outlook and ceremonial basis for ancient Weltanschauung which doesn't describe the world consistently but aspires to imagine it and symbolically explain the general picture equating the subjective and the objective. On the other hand, a myth and a ritual are two forms of expression of the same symbolism which offer a variety of 'poetic figures' and possible situations which may be realized in a folklore text. And the folklore, assigning a word the significance of the main means of cognition and expression, preserves these archaic conceptions transforming the mythological thinking into the art of word. This, undoubtedly, is the most generalized context of this set of problems.

Let's start from a ritual. Here, the very contents but not the form, active but not passive basis determines its essence. From this point of view, a ritual may not be isolated from development of a human community and development of the forms of the human spiritual culture. A ritual is also inseparable from the folk song creation. This may be understood so: everything which is sacral, holy, stable and effective - a word, an action, a thing - is regarded as valuable introducing them into the symbolic order. They are the verbal and non-verbal phenomena which may be found at the origins of creation and may be continuously reproduced or translated at the level of feelings and images, i.e. in the space of subjective reality, in the folklore tradition through a ritual. In the W. Turner's opinion, this is properly the purpose of a ritual: ritual is a collection of symbols as narration of information about the most important values and their hierarchy as a system of needs and means which might have no religious meaning, as a product of interaction of various social statuses and states (Terner, 1983).

"However, the ritual studies don't try to prove as if all the elements and functions of a ritual inevitably pass to all kinds and genres of the folklore culture. As for a lyric song, a ritual background is more natural for it. It manifests itself in many ways simultaneously. First, a lyric song is obliged for its origin to ritual songs, and only at the significantly later stage of the development, it gets its stylistic form. And secondly, as O. Bodianskyi wrote, 'in its own and strict sense, there is no pure and independent epics, lyrics or drama or, saying about them separately, one always means prevailing of one of them over the others' (Bodianskiy, 1837, p. 70). The fact that a folk lyric song redevelops, modifies, transforms the ritual and mythological models in accordance with its lyric and functional structure which in many respects determined its artistic and poetic world doesn't define yet the relations with what preceded the song creation. These relations may be defined within two outlooks. The first outlook would allow revealing the peculiar logic of the structure of mind, consciousness, knowledge, imagination which generates a myth, a ritual and the folklore as well as those sense-forming processes which are concealed behind such logic: the identity with the archaic thinking where there no clear borders between the specific and abstract bases, the subject and the object, a thing and a sign, the single and the plural, the spatial and temporal relations.

The second outlook presupposes the study of the poetic thinking, its process in the folklore through existence of steady ritual and mythological models and their variants in the song texts which reveals, first, the stereotypes and mechanisms of existence of the folklore consciousness as mental directives evoked by the mythical and ritual position. Secondly, nothing but they form the ethnic and poetic consciousness, model the artistic picture of the world and are projected on the folk song creation genres. Such approach would allow revealing all signs of inseparability of the folklore lyrics from the mythical and ritual paradigm: the stereotype and repetition, sensual and emotional way of experiencing the reality, social communicability, metaphoric form of comprehension of the world. 
Stereotype and repetition. As is well known, the everyday lyric song as a folklore text really exists only at the time when it is performed. However, even then, it's always just one of the variants, which involves stylistic, plot-specific and thematic stereotypes modifying or transforming them. The performer's memory always keeps a certain stable and variable structure of development of the theme, plot, typical everyday life and ceremonial situations, constant characters and verbal formulae, genre etiquette, which determines the specifics of functioning of a folk song. One of the causes of such logic and mechanisms of existence of traditional culture was neatly defined by $\mathrm{M}$. Eliade as 'the eternal return' (Eliade, 1987, p. 60). This especially relates to a lyric song where compulsory and continuous resort to the examples of profound and important information is fundamental, provides it with fresh motives and new feelings, leads to formation of the artistic and poetic structure. This thesis inevitably generates another one: it should be recognized that in determining the qualitative, in particular, musical features of a song as a units of measurement, the crucial importance belongs not to its everyday function but the axiological directives of the specific ethnic environment, 'the thinking modus' of the environment (Gritsa, 2000, p. 95), individualization of feelings which are common for the whole environment, i.e. what may be called a lyric genre. Essentially, the song folklore reproduces the functionality of a higher order, i.e. orientation of the environment to a certain type of thinking reflected in the form and style of the pieces of art but not just some 'level' in the quantitative meaning achieved by culture at the new stage of history.

Both such traditionality and continuous reproducibility of a song text in the act of performance is ritualized to a certain extent. This feature is directly associated with another one. Although lyric songs are not explicitly associated with a certain ritual scheme but internally they always are associated with the reality, are filled with vital material, respond to a great number of the social life themes and therefore, in the very act of performance, possess a certain ritual nature and correlation with the dynamics and regulations of the group's life. In this sense, the performance of a song constitutes a ritualized act, i.e. standardized and arranged act predicted by the tradition. And so the song genre receives the typical, formula nature getting released from the risk to get lost in the everyday life empirics. Finally, the formula distance provides a lyric song with a possibility to continuously take part in and have influence on the social life. Hence, at least three essential features of ritual nature of lyric songs appear: reproducibility, verbal stereotype and regularity but emphasized semiotic nature; the sacral nature of the verbal information entitles the folklore text to reproduction; its stability and mobility contribute to formation of the artistic and poetic structure of a song. However, without taking into consideration the psychological functions of a word and rhythm, the genre picture of a song would be incomplete.

The sensual and emotional way of experiencing the reality. A lyric song almost always is a psychophysiological phenomenon. The pragmatic nature of this most emotional and existential folklore genre, in addition to the informative function, envisages the compensatory and emotional discharge in it. In a song, the principle of psychological coding of information, semantic polyphonism in the representation of a phenomenon, act, idea which are forming strongly manifest themselves, on the one hand, at the level of rational and emotional cognition of the reality and, on the other hand, adjustment of the 'vital world'. In this psychological process, it turns out that we perceive a song not as a verbal or musical text only but as a way of achievement of so called emotional comfort. The same principles may be found in every lyric song: continual codependency (but also permanent discrepancy) between a man and the reality takes place. The persona's emotional responses to life events (grief, sorrow, despair, discouragement, bad luck, injustice, distress, loss of a beloved person, betrayed trust, impediments occurring during life) and glowing desire to 'transform' the surrounding world come to the foreground. However, the permanent opposition of this interaction may not always be solved in everyday life. In this case, a 
lyric song as a verbal model which symbolically fulfils the cathartic function -'purgation from passions' according to Aristotle or 'deliverance of aggressive energy' according to C. Morris formally may not be distinguished from a ritual the role of which it is ready to adopt. Finally, the song creation always preserves the most important function of a myth and a ritual which is reduced to an individual's involvement in the circulation of life of the community and nature where overcoming of the opposition of the state of microcosm and the state of macrocosm conceals a creative basis. Both for a man and the art, especially when contrasts between the human soul and the world are played and it seems that there are no common conditions for changes, the very processes of transformation have something common, similar which may almost entirely be derived from a ritual.

It has been already said that the concept of a norm and a rule which were considered to be inherited from the ancestors but not violation of them, priority of the general over the exceptional determines the traditional type of culture. Continuity and traditionality of the folk culture oriented to samples (myth, ritual, symbol) when the past explains the contemporaneity, the past experience predicts the future, are always aimed at the future. In this respect, the mechanisms of action and existence of a song text coincide or correlate with ritual repetition the purpose of which is renovation, rebirth and correction which however never aim at creation of new forms but only repeated development of the old ones. This process of evolution of the ritual structures in the folklore songs manifests itself rather obviously. One thing is that ritual and magic influences are opposed by poetic fantasy, artistic and aesthetic system, and a new main 'figure' of a lyric song - parallelism - succeeds the magic and ritual canon. In a song, it is perceived as decorative means. However, simultaneously, poetic formulae, being repeated in the song texts, prepare predominance of the ritual basis oriented to confidence in self-sufficiency of a psychical state of a group or an individual which in lyrics relates not so much to the level of context but rather the level of expression of both aesthetic emotions and the psychical state of the performer-listener. Due to the psychological function of a word, the lyric song finally receives own stylistic, sensual and emotional rituality.

We remember: traditional culture is aimed not at augmentation of texts but reproduction of a sample text. In the folk poetic creation, which is mimetic by nature, the role of memory in reproduction of the world outlook and artistic experience of the mankind is assumed by a myth (not in the meaning of narrative but as a manner of the world sensation) as well as a ritual and a symbol as a regulating and creative function. This is the mythological experience which further is symbolized into pieces of art. It's well understood that just like in these different human intellectual activity spheres (a myth and a ritual), in a lyric song, super personal information is communicated with different filling, in its own structural forms and with a certain functional orientation. And this is inseparability of the verbal program of a ritual from the ritual itself (a distinctive feature of all archaic cultures) that tells not so much about the interrelation of the verbal and nonverbal parts of a ceremony as about the ceremony itself marked with the unity of a word and an act and, above all, about the especial, absolutely independent role of a word which, in the archaic traditions, acts and exists as if it is independent from solemnizing of a ritual, has the selfcontained value and vested with a great suggestive power.

Social communicability. If we agree that a word in a ritual first of all presupposes the existence and functioning of a verbal text in ritualized acts as a regular structural element, we should also agree that performance of a song text is also always motivated by the background of events, external situation which resembles not only a choice of a certain genre but often a choice of a specific piece of art within the limits of the 'genre element'. Finally, this type of connection between a song and a ceremony may vary, at least when for example a nuptial ceremony includes pieces of non-nuptial songs (properly lyric, dancing and joking). Some songs not only reveal their sense in the context of 
ritualized actions or time framework (for example, songs about love sung by youth at promenades and parties) to the fuller extent but sometimes lose their semantic filling out of a ritual as, for example, openly erotic 'Perezvianski' songs that are performed at the certain moments of the marriage ceremony only. And just in the context of rituality, one may see the specificity of any song text.

This feature of functioning of folk songs, which is ritualized to a certain extent, predetermined their intrinsic set of meanings as a ritual structure and as just a folklore text. In that way, their contents reveals not in a narrow sense of a combination of words in a poetic text but as a wide description of the reality a picture of which is somehow reproduced in the verbal part of the ritualized action. And here, one should remember that formation of a genre context of lyric songs (family-life-specific, social-life-specific, dancing or joking) is preconditioned by certain typical situation of everyday life, functional and structural links with cyclicity of life and activity of a group of people or group orientation in the reality. Indeed, a song is always included into a certain stable traditional out-ofsong system and constitutes a single whole with it. Out of this system, it may neither arise nor exist. The situational nature and functionality of lyric songs determines their origin (for example, songs for dances, tchoomaks' (Ukrainian oxcart drivers'), artisans', immigrants') and explains their 'ideology', regularity of creation of a poetic picture of the world which is modeled taking into consideration the extra-textual relations as well. Confidence in the correlation between a song and a ritual at the different levels, starting from the inclusion into the very ceremony or the correlation with its certain stages up to the ceremonial, ritual and mythological field, leads to the specific ceremonial background in a lyric piece of art. In songs, it may be imagined, for example, as a system of relations between the participants of a ceremony (as the part of the groom and the part of the bride in the nuptial songs or, more generally, the binary opposition of masculine/feminine, his/her canon in the songs about love). In another respect, the ceremonial background in the lyric songs is associated with non-randomness of the text of piece of art, its traditionality which communicates no new information to the participants (the performer and the listeners).

The nature of what we vaguely called 'traditionality' defines the very correlation of an act with repetitiveness and formulaicness in a folklore text. Likewise, one of the essential tendencies of verbal poetry is the return to the folklore 'continuum'. That's not the point that in a song text one would find no expressions which explain the sense of the message. This function is possible because the 'language' of folklore allows us to have read it through certain established meanings the sense of which is known to a carrier of the tradition and is sacramental for this type of culture. A ritual has a close situation: a phenomenon or a thing, in several cases, in the verbal part of the ceremony, is not described because it is nearby during solemnization of a ritual or just because that the meaning of an object is already known both for the performer and a passive participant of the ritual because they both are speakers of the same 'language'. The influence of the tradition on a lyric song is not 'semiotic' only: as traditionality and motivelessness of a song text grows its performance, just like performance of a ritual, is established regardless of the sense of the text.

But for understanding of the essence of a ritual not only at the operational, 'technological' level, the following statement remains important: a ritual is used not for confirmation or inculcation of a fact which has already occurred. It constructs and creates it and finally constitutes such fact through which the essence of a ritual and its profound sense as a creation is expressed to the fullest extent. In this situation, a ritual continuously actualizes, puts and solves a lot of super-symbolic issues which also relate to the mythological level: detection of differences establishment of relations between different variants of the human/nonhuman opposition, removal of the life/death opposition, establishment of the relations of similarity between the human and the world. Finally, at the early stages of development of the human thought, the difference between the world itself 
and its perception by a man didn't exist. A man just tried to subjectively reproduce the environment without opposing I and non-I, and the world, imagined by a primordial man, is created by the man's subjective consciousness again as the second objective reality. And such world outlook and ritual basis of the ancient Weltanschauung which describes the world inconsistently but tries to imagine it and explain the common picture identifying, according to O.Potebnia, 'the subjective and the objective' (Potebnia, 1989), a myth and a ritual. And folklore, giving a word the significance of the main means of cognition and expression, keeps this closed repertoire of images.

Metaphoric form of comprehension of the world. It is significantly more difficult to notice the phenomenon of 'myth' on the terrain of poetics of verbal lyrics. So, the next part of our considerations about the genesis of alyric song has to be related to 'mythopoeia'. The well-known and the most common way of search of the mythical in folklore pieces through its opposition to the sphere of mental being, emphasizing the differentiation of facts of verbal creation from other ways of artistic expression and manifestations of the human psychical activity restricts our understanding of this phenomenon. The cause is the concept of a myth as just the complete identity of a certain idea and its material image in a word. However, the mythopoeia becomes a way of the man's attitude towards the word and determination of his place in it although the mythical and poetical remains inseparable from mythological 'corporality' because a word-symbol, according to philosophy, is 'a visible body of some invisible soul' (Florenskiy, 1990, p. 224-225). Thus, one could say that in a folklore song text, we cognize the mythopoeia through stereotypes - archetypes, symbols, metaphors - or just through a word and attempts of its translation by means of poetry. But this is only one of the functions of a myth in the folk poetic practice.

Transmutability and imperceptibility of the meaning of a myth is the assessment given by almost all its researchers. The history of the notion 'myth' also convinces of its multifunctionality. The reference literature regards a myth and a religion as dependent forms of culture and ascertains that the word 'myth' of the ancient Greeks meant a narration about acts of gods and heroes, a tale, a legend, a retelling or fable i.e. any story to which truthfulness was attributed or which was taken as a fiction (Kovaliv (Ed.), 2007). For example, for Plato, a myth was firstly a poetic function and secondly a fantastic story. However, in the Aristotle's 'Poetics', one of the meanings of the word 'myth' is reduced to the modern meaning of the word 'fable' (Kuz'ma, 2008, p. 334). The modern humanities, going beyond the limits of the historical roots of the narrow meaning of the word 'myth', interpret this 'synthetic product of intellectual activity' (Davidyuk, 1997) as a system of rational knowledge, an aesthetic canon or system of emotional cognition, substantiation of morals, customs and rituals that is to say as the origins of culture and vital condition of the artistic over centuries. This is the evolutionary way from the primordial, 'primitive' consciousness to the arts which is defined in the scientific position of I.Franko who in his studies 'The Remains of the Primordial Thinking in the Ruthenian and Polish Folk Riddles' writes: 'what was the contents and a storm of spiritual life for a primordial man, for us is just an adornment of life, and ideal toy of imagination; what once was religion now is poetry' (Franko, 1981, p.333). Thus, the dualism of a myth gives birth not only to various scientific approaches to study thereof but programs different artistic findings of the mythological in the folklore texts.

In this sense, one may say that the poetic thinking should be understood as a phenomenon which is analogous to the mythological but not identical. In one respect, we have the understanding of verbal poetry as a peculiar extension of archaic folklore (rituals and ritual songs);in the other respect, as an idea of the hierarchy of codes which came from the mythological thinking and the folklore phenomena of more ancient times; and in one more respect, if a song contains a mythological or polysemantic motive, for example, life, death, soul, destiny, road etc., usually it's an image which has been already interpreted often using the mechanisms of social symbolization 
and lyrization. Moreover, the two types of thinking (mythological and poetical) tell not so much about pieces of culture as about people who create them. Accordingly, a lyric song perceives a myth and a ritual as a creative principle, as multifunctional symbolic mechanism which is vitally important for existence of the genre of the folk culture and featuring the integral and constructive function.

Another argument in the answer to this question could be found in those researchers of mythology (K.Jung, S.Averintsev, A.Losev) who expressly associated a myth with the reality, defined it as 'the very life', regarded it not as an idea or concept, a scheme or allegory, but a narration which was taken as the reality, precisely, as reception of the reality. So it's natural that under such circumstances, in a lyric song turned to the primordial unity, a myth, the mythologized reality manifests itself at least in two kinds. The first is about images of things, their prints as symbolic indicators of a psychologically complete image of a man. The second kind is defined by the fact that, in a song, a personality itself belongs to symbols, it recognizes itself in a myth as a collective work of the past, experiences it in a word.

In addition to this fundamental relation, between a myth and a subject in a lyric song, there is an unconscious process of search of a ready solution, a response to some difficult and insurmountable situation by a man at the moment of the emotional stress. Such actualization of the psychological state of the persona in a song is important because exactly it creates the mythical nature where the character is. It proves then the analysis of plots of lyric songs where it is not the event or time aspect that attaches development to them but they are created by the dynamics of development of a thought, a mood, an expectation, a desire, a reflection, an emotional experience. Incidentally, ethnolinguists, ethnologists, psychologists and neuropsychologists are sure that such ready solution of a conflict situation probably is a mythological explanation, introduction of a metaphoric image, which was formed on the basis of similarity or time overlapping of some facts, into consciousness (Voronin, 1982, p. 9; Bayburin, 1993, p. 10; Cherepanova, 1996, p. 114; Porshnev, 1974, p. 437). However, it would be illusion to believe that such wording of the question releases a verbal poetry researcher from involvement of axiological problems related to the system of value-based orientations of the real life.

Touching upon the dialectics of the subject and the object in cognition, emphasizing the active participation of a man in formation of a poetic image of the world, we should simultaneously notice: a myth itself for the primordial consciousness was not a word-narration but a word-reality which was 'emotionally experienced', 'replayed', 'reproduced' in mysteries-actions, and mythology was real-active, emotional-vital because identified an image-word with the reality itself. The most obvious manifestation of this process in different types of culture is the origin of variations of the well-known mythological systems. A myth enabled a man to compare his individual experience with the universal experience models. A myth appears not only as an early history of the mankind but as some comprehensive formula, a code to understanding of not the past only but also the present and the future mythologizing the reality.

For example, in 'The Primordial Thinking' by Claude Lévi-Strauss, the author of the theory of the mythological thinking as a sign system, the following conception can be found: a myth is a category of the modern thinking which is voluntarily used to unify the attempts to explain natural phenomena, pieces of verbal culture, philosophical concepts and cases of the origin of linguistic processes in the subject's consciousness within the same term (Levi-Strauss, 1994, p. 45). This idea leads to the following conclusion: a myth is polysemantic and able to embrace different phenomena of the human activity. Indeed, in archaic societies, the social and psychological functions of a myth explain laws, ethical values, they become a basis for beliefs, traditions, code the conduct rules and generally all the aspects of human life uniting closely with rituals. Simultaneously, the mythopoetic 
thinking, being defined by the unity of the spiritual and the natural, made and makes an ideologically, thematically and aesthetically polysematic song a successor to activity of a myth. The point is about the property of verbal lyric as a later stage folklore form to repeat the typical archaic models in new and significantly transformed modi: in poetic motives, symbols and images modified under the increasing influence of the aesthetic, emotional aspect. Until being recorded, the Ukrainian song tradition had acquired real and social, sensual coloration.

There is one more important aspect. We should realize that a folklore text is an element of traditional culture and as the art of word. This is the combination of features that determines the semiotic nature of a lyric song taking into consideration its underlying relations, ritual and magic, social and everyday life functions because from the point of view of the origin, to a great extent, it appears a late result of decomposition of the initial ritual inseparability and oblivion of the initial mythological senses. But a folk song, assigning a word the significance of the main means of cognition of the 'vital world' and its expression, preserves this repertoire of code in the aesthetic outlook. This repertoire is of an open nature. Mythologemes (motives or images of a mythological system) may be not only the means of arrangement of the world but a total, typical or predominant way of the artistic thinking of not only archaic cultures but they may enter into cultures of the most different types, especially into literature and art, at the level of a certain fragment, metaphorism aimed not only at the verbal, acoustic, visual comprehension but also at the aesthetic one.

Thus, a lyric song in the genre aspect is formed at least in two dimensions. The first is determined by a ritual through the relations of action of the tradition in the song motives or orientation of a song to repeated communication of an ethnic text. However, the second dimension adds perception of a ritual itself which is the centre of formation and being of a lyric song as a projection of the sphere of mythology. But what conditions should be met by a myth and a ritual in order to build a genetic definition of lyrics? O.Veselovskyi wrote about it creating his 'historical poetics'. The scholar tended to regard a folk ritual as an important part of 'synthetic art' and a source of not only dance, music but also poetry. A myth and a ritual (as it is generally proven by the Veselovskyi's theory of primordial syncretism of game forms although ignoring the primordial thinking syncretism, the 'world outlook symbiosis' (Freidenberg, 1998, p. 19) are combined not so much by their common origin as by the semantic unity which is the most important feature of the early forms of art. And since the primordial human consciousness features specificity, repetition, singlepurposefulness of the past and the present, the old remains in the new. Veselovskyi deduces lyrics, like some features of the folk poetic style, in particular from the spring ceremonial games, from emotional exclamation of a chorus and expression of 'collective emotionality' showing the semantic etymologic closeness of the ideas of song - word - action - dance as well as song charm - divination - ceremonial act and associates distinguishing of lyrics among other poetry genres with individualization of poetic consciousness. Academician Veselovskyi theory of primordial syncretism had to explain the genesis of poetic forms. But it should also correlate with the peculiarities of the poetic style which the scholar understood as a phenomenon similar to a myth however independent from a myth itself because 'relation among a myth, a language and poetry is not so much in a unity of narration as in the unity of the psychological means' (Veselovskiy, 1940, p. 133). In this context, the primordial art syncretism should be understood not as mixing but absence of differences between certain poetic genres and other arts.

But syncretism of the primordial thinking we are talking about is a certain project of creation in general. This is where the said integrative and constructive function of a myth and a ritual appears. We remember: since a myth, like a ritual, is a law, a world outlook but with the difference that this is an idea of the world expressed in a word, so the border between a ritual and a myth at the level of the essence, subject is not so much noticeable and a ritual represents a form of realization of the 
mythological concepts of the world, a model of the world. In short, a myth and a ritual are equal semantically. And this semantic unity of a myth and a ritual (ideological syncretism) is an indispensable prerequisite of primordial syncretism of arts and genres of poetry and the most important feature of the early forms of art. However, it also relates to the later forms of the human artistic practice, verbal lyrics. At the semantic level, syncretism of a myth and a ritual in a folk lyric song demonstrates unity because they (a myth and a ritual) describe the same object, macrocosm through the human world outlook, through the human microcosm.

The relation of a non-ceremonial song to a myth and a ritual is not only a problem of genesis of a genre phenomenon. From the present point of view, the most important is a deed of description of the laws of mythological consciousness and myth creation in the development of the poetic form of verbal lyrics. Simultaneously, finding and study of the archaic forms of consciousness in a lyric song requires also distinguishing of other folklore material which has both textual and non-textual relations with it. In such selection of genres, priority must be given, naturally, to ceremonial songs (Vesnianky, Koliadky, Shchedrivky, Kupalski and Petrivchanski songs, nuptial songs and lamentation) not only in the aspect of the thematic closeness but as such that preserved the archaics and ritual and mythological features to a fuller extent. And in order to nearer to adequate understanding of folklore stereotypes in a lyric song as close as possible, it is necessary to involve other material: 'small' folklore forms (wishes, magic sayings, ritual charms, text accompanying divinations, acts of magic, quackery, production and everyday life practice etc.) which are valuable not due to their high level of non-textual relations deeply rooted in the context of ritual behavior but the high level of establishment and formulaicness which allows to preserve the figurative elements of the archaic levels of culture.

From the researcher's outlook, the regularity may be read: in the pieces of verbal lyrics, there are two planes of functioning of the archaic levels of culture. The first one is when a song abundantly uses specific mythologemes and transforms them into a 'poetic language figure' depending on its genre structure. And the second one is when the poetic language of a lyric song noticeably contributes to preservation of the mythologeme semantics, profound sense separating it from the main ritual, main genre or the original conception which have already disappeared or become obliterated in their pure form. Thus, the ancient culture lives in a new, song culture developing according to the internal laws of mythology and in the new metaphorized form manifests itself in the poetic thinking. The set of codes adopted within traditional culture may be deemed a symbolic model of such culture, which in a lyric song has been built up as both the plane of expression and the plane of contents. At that, in its second meaning, i.e. as a verbal text, it appears not so much a separated form of the human conception of the world as a form of correlation with other texts of the culture which are a myth and a ritual. In the philosophical aspect, the entire problem of the ancient consciousness has been generally expressed in its basic principles as mythological dualism or, according to Lévy-Bruhl, as a 'mystical participation' between a man and the surrounding reality.

Reproduction of the archaic Weltanschauung is not an easy task though. But one of the features of the world outlook of an ancient man is preserved by folklore. In the genetic chain 'dualism folklore - lyric song', the creative conception of the world is transmitted through the double opposition as a universal tool of rational description of a picture of the world and a way of determination of its existential, spatial, temporal, social and other features (for example, life/death, sky/earth, top/bottom, near/far, right/left, even/odd, big/small, male/female). This primitive 'philosophy', naturally, reveals the naïve dialectics of the primordial thinking which perceived the world, an object or an action only in the form of a double unity, in the form of paired oppositions which directly don't exist. But this universal technique of opposition easily expanded to the entire 
sphere of culture. The principle of the mythological thinking (existence according to a prototype) is also reproduced by a lyric song which represents primordial phenomena of being of a man, binary nature of the personality, inconstancy of the human mind. Through mythological motives and symbol-signs, it actually transfers the dialectics of the simplest spatial and sensual orientation of a man into the plane of the 'personality' of a persona and even introduces a certain emotional field. And here, we should note that all these 'codes' and 'structures', which were the basis for creation of a picture of the world which explained and organized it, were, materially, mnemonic techniques i.e. sense points in the art of memorizing, in a system of specific means which facilitate to consciously memorize the essential and significant, to keep and reproduce this information mainly by means of formation of associations, in images and impressions which are 'analogues of the reality'. The mythological tradition cares not for simple explanation of the world but preservation thereof.

\section{Conclusion}

Summarizing the considerations about genesis and evolution of a lyric song, one may look at them from two points of view. In the historic outlook, the folk song lyrics of $17^{\text {th }}-21^{\text {st }}$ centuries does not resemble archaic poetry which accompanied calendar or family rituals with its specific sensation of the world and respectively with the way of the lyric expression. Therefore the most essential would be changes in the genre as the most distant, for example, from a ritual and not directly related to the specific conditions and circumstances of the performance. But the process of formation of the genre phenomenon may not be interpreted as just mechanical and be confined to simple borrowing of thematic repertoire or some stylistic means. Each folklore genre is totally independent not only by the thematic contents and poetics but by the role it plays in the everyday life spheres.

A lyric song, as a 'young' genre of the folk poetic creation, seems to have most of all out-of-ritual existence and is related only to the adaptation of a plot to the reality. However, we have been repeatedly convinced that this is insufficient for determination of non-ritual nature of a songbecause the fact of its performance itself is a ritual and that it seems that there no pieces not attributed to certain circumstances of the performance at all. Since it's difficult to believe that it's normal for existence of songs to be performed 'for oneself', in the private, so each of them has its circumstances of performance (dance, morning songs, evening party songs, street songs, send-off etc.), i.e. actually one may only say about the appearance of songs in one or various non-verbal environments. But the song structure itself is a conductor of both internal links within a piece (its separate elements, the word and the tune) and the external ones (dedication to a ritual action, conditions and manners of the performance). Due to their traditional adjustment, the texts of lyric songs go far beyond an artistic description of real vital events exposing themselves as a certain ritualized act. Songs contain the ritual-symbolic and mythological aspect which is more informative giving sense to whatever happens. We should also acknowledge that the poetic consciousness of the creators of the song folklore kept being mostly mythological although considerably obscured for a long time. In lyric songs, even real events (life, death, love, happiness, grief, destiny, good, evil) correlate with those models which are contained by the collective memory and super individual experience; their meaning is weighted according to the scheme of the mythological model of the world, and everything going beyond the framework of the stereotyped experienced is declared unimportant. Therefore, the assumption that a lyric song must be accompanied by a mythological or a ritual background seems to be very probable. And in this case, it has even some advantages in comparison with a myth or a ritual, however, not at the level of inclusion of some archaic elements but as an active participant of realization of the world outlook models, 'pre-metaphors' which are not explained by a song text but they explain everything in it. 
Although, certainly, mythological and ritual semantics of the plots, motives or symbols is not realized by the folklore creators like, for example, the antique folklore doesn't understand or remember the semantics of a myth.

\section{List of References}

Bayburin, A.K. (1993). Ritual v traditsionnoy kul'ture: Strukturno-semanticheskiy analiz vostochnoslavyanskih obryadov. SPb.

Bodyanskiy, O. (1837). O narodnoy poezi slavyanskih plemen. M.

Cherepanova, I. (1996). Dom kolduni: Yazık tvorcheskogo Bessoznatel'nogo. M. Veja.

Davidyuk, V. (1997). Pervisna mifologiya ukrainskogo folklore (monografiya), Lutsk:

Denisyuk, I. (2005). Natsionalna spetsifika ukrainskogo folklore: Materiali po lektsii, L.

Eliade, M. (1987). Kosmos i istoriya: Izbrannye raboty (monografiya). M.: Progress.

Florenskiy, P.A. (1990). Stolp i utverjdenie istiny (monografiya). 1. M.

Franko, I. (1981). Ostanki pervisnogo svitoglyadu $v$ ruskih i polskih zagadkah narodnih. K.: Naukova dumka.

Freidenberg, O.M. (1998). Vvedenie v teoriyu antichnogo fol'klora. Lektsii. Mif $i$ literature drevnosti (monografiya) (10-122). M.: Vostochnaya literatura.

Gritsa, S. Y. (2000). Fol'klor u prostori ta chasi: Vibrani statti (monografiya). Ternopil.

Kovaliv, Yu.(Ed.) (2007). Literaturoznavcha entsilopediya. 1. K.

Kuz'ma, E. (2008). Kategoriya mifu v literaturoznavchih doslidjennyah. Teoriya literaturi $v$ Polshi. Antologiya tekstiv. Druga polovina XX-pochatok XXI st. (332-351). K.: Vid. Dim "KievoMogilyanska akademiya".

Levi-Strauss, C. (1994). Totemizm segodnya. M.: Respublika.

Porshnev, B.F. (1974). O nachale cheloveskoy istorii: Problemiy paleopsihologii. M.

Potebnia, A.A. (1989a). O dole $i$ srodnth c neyu sushestvah, M.: Pravda.

Potebnia, A.A. (1989b). O mifologicheskom znachenii nekotorth obryadov i poveriy. M.: Pravda.

Terner, V. (1983). Simvol i ritual (monografiya). M.: Nauka.

Veselovskiy, A.N. (1940). Istoricheskaya poetika. L.: Gosudarstvennoe izdatel'stvo "Hudojestvennaya literatura".

Voronin, S.V. (1982). Osnovly fonosemantiki, L. 